\title{
Palm Oil Mill Effluent Treatment Through Combined Process Adsorption and Membrane Filtration
}

\author{
Muhammad Said $^{1 *}$, Siti Rozaimakh Sheikh Abdullah², Abdul Wahab Mohammad ${ }^{2}$ \\ ${ }^{1}$ Department Of Chemistry, Fakultas Mathematics and Natural Sciences, \\ University of Sriwijaya \\ ${ }^{2}$ Department Of Chemical and Process Engineering, \\ Faculty of Chemical Engineering and Built Environment, National University of Malaysia \\ *Corresponding author.email: saidusman2011@gmail.com \\ Article history

$\begin{array}{llll}\text { Received } & \text { Received in revised form } & \text { Accepted } & \text { Available online } \\ \text { 19 May 2016 } & \text { 16 June 2016 } & \text { 4 July 2016 } & \text { 15 August 2016 }\end{array}$

\begin{abstract}
The growth in palm oil production also leads to an Increase in the production of palm oil mill effluent (POME). Nowadays, POME was treated using an open lagoon but this method is ineffectiveness in complying with the standards for water disposal. Therefore, efficient and cohesive treatment system is highly desired to ensure the final discharge of the treated water meets the effluent discharge standards. Initially, the POME was treated through adsorption, followed by UF membranes roomates were intended to reduce COD, TSS and turbidity up to $88 \%, 99 \%$, and $98 \%$, while the final treatment of RO membranes can reduce BOD, COD and color up to $92 \%, 98 \%$ and $99 \%$. To determine the optimum condition of the RO membrane, response surface methodology (RSM) was used. The results showed there was correlation between all key variables. POME concentration, trans-membrane pressure, $\mathrm{pH}$ and time would give significant effects in reducing the parameters in POME treatment with the optimum condition of $15.77 \%$ for POME concentration, 3.73 for $\mathrm{pH}, 0.5$ bar trans-membrane pressure and 5 hours for filtration time. To predict COD removal, the results were analyzed by applying the artificial neural network (ANN) to derive a mathematical model.
\end{abstract}

Keywords: POME, Adsorption, Membrane filtration, COD, RSM, ANN

\begin{abstract}
Abstrak (Indonesian): Pertumbuhan produksi minyak kelapa sawit juga meningkatkan produksi air buangan minyak kelapa sawit (POME). Sekarang ini, POME diolah menggunakan kolam terbuka tetapi metode ini tidak efisien dan tidak memenuhi persyaratan standar air buangan industri. Oleh karena itu, diperlukan suatu sistem pengolahan yang efektif dan terpadu untuk memastikan air buangan pada tahap akhir telah memenuhi standar air buangan. Pada awalnya, POME diolah melalui adsorpsi dan diikuti oleh membran UF dengan tujuan untuk mengurangi kadar COD, TSS dan kekeruhan hingga 88\%, 99\% dan 98\%, masing-masing. Sementara itu, pada proses akhir digunakan membran RO yang berhasil menurunkan kadar BOD, COD dan warna hingga 92\%, 98\%, dan 99\%, masing-masing. Untuk menentukan kondisi optimum dari membran RO digunakan metode respon permukaan (RSM). Hasil memperlihatkan ada korelasi antara semua variabel. Konsentrasi POME, tekanan trans membran, $\mathrm{pH}$ aturan dan waktu memberikan pengaruh penting dalam pengurangan parameter pada pengolahan POME, dengan kondisi operasi optimum sebagai berikut: $15,77 \%$ bagi konsentrasi, 3,73 bagi $\mathrm{pH}, 0,5$ bar bagi tekanan trans membran, dan 5 jam waktu filtrasi. Untuk memprediksi penghilangan COD, hasil diperiksa menggunakan metode jaringan saraf tiruan (ANN). Hal ini bertujuan untuk mendapatkan suatu model matematika.
\end{abstract}

Kata kunci: POME, Adsorpsi, Membran filtrasi, COD, RSM, ANN

\section{Introduction}

Malaysia and Indonesia is the biggest palm oil producer in the world. More than $80 \%$ of palm oil in the world comes from Indonesia and Malaysia. Every year there is an increasing in crude palm oil production, which means the increase in government revenue because more than $80 \%$ of palm oil is exported. However, the increasing of palm production oil is also means increasing of water consumption. To produce one ton of palm oil, about 5 tons of water required and most of the water will end up as waste water or Palm Oil Mill Effluent (POME) [1].

POME is a colorless liquid remains dark brown but not toxic because no chemicals are added as extortion palm. POME consists of $95-96 \%$ water, $0.3-0.4 \%$ 4-5\% oil and solid particles including 1-2\% TSS [2]. It was dominated by organic material (COD around 50,000 mg / L and BOD 25,000 $\mathrm{mg} / \mathrm{L}$ ), has an unpleasant odor and 
highly polluting. Based on these characteristics, it is rally necessary to find a new processing method that is cheap and efficient.

Nowadays, the processing POME use an open pit treatment. However, this method has limitations in water discharge standards. In addition, open pit treatment requires a large area and longtime processing [3]. Therefore, integrated system is needed to ensure the final product of the water meets the effluent discharge standards into the river.

This study focused on integrated processing using the method of adsorption and membrane ultrafiltration and reverse osmosis. Some parameters were targeted to be eliminated such as BOD, COD, TSS and color. To search for optimum conditions, it is used response surface method (RSM) and to predict the COD removal required a reliable ANN model. This will reduce operating cost and maintaining product quality. The more input data is used, the better the prediction is generated.

\section{Literature}

Open lagoon system is the most commonly used in Malaysia and Indonesia. Approximately $85 \%$ of the palm oil mill use this system. This method is popular because this method easy to operated and having low operating costs. But this method has the disadvantage of requiring large land space and the releasing of gases produced in the treatment process will lead to a greenhouse effect to atmosphere. In addition, inefficiencies in meeting wastewater discharge standards [4]. Therefore, an effective processing system is highly preferred as an alternative to conventional treatment to ensure the release of the final release of waste water meets the standards imposed by the government of Malaysia and Indonesia.

In recent decades, the use of membrane technology in wastewater treatment has increased rapidly. Include the wastewater treatment of POME. Membrane filtration is believed to have the ability to produce clean water in a short time, reduce the useful of area and power, and constant quality of water produced. The application of membrane technology is always preceded by a pretreatment process. It aims to remove suspended particles and organic material in the POME. This action is useful to make longer lifetime of membrane and gain the better product.

For example, Wah [5] compared three methods of pre-treatment (coagulation, centrifugation and filtration) prior to membrane processes Ultra Filtration (UF). The results showed that the combination of filtration and UF membranes are the best to reduce the content of POME. Meanwhile, [6] using a six-treatment prior to an POME screened with two different types of molecular weight cut off value (MWCO) of UF membrane. As expected, the membrane with a lower MWCO may resist the particles and then produce a high flux of flowrate.
Ahmad [7] design three systems combined UF and RO membranes are called A, B and C. The results obtained in optimum condition indicate that the water quality is obtained for the design of A, B and C effluent discharges meet the standards imposed by government. The economic analysis shows that the number of processing costs for design A is the highest (RM 115.11 / m3), followed by the design B (RM $23.64 / \mathrm{m} 3)$ and the design of C (RM 7:03 / m3). Design C is selected as the optimum design for membrane based POME treatment system based on the low costs of the processing and the quality of water meet the standards of effluent discharges.

Adsorption is a major method that is used in the pretreatment process. Adsorption has advantages in terms of conformity to treat wastewater with high pollutant content. One of the adsorbent commonly used is Activated Carbon. The activated carbon has stability and high reliability. Utilization of activated carbon as adsorbent not only apply to the waste water treatment but also in gas purification and removal of heavy metals. However, activated carbon adsorbent has a disadvantage i.e. it can be used repeatedly so it will increase the cost. This led researchers to look for the new adsorbent.

Montmorillonite is a natural adsorbent used. Montmorillonite has a large surface area and chemicalmechanical stability of the structure, so it has good absorption capacity and ion exchange ability. Montmorillonite has two layers sandwiching a layer tetrahedron-shaped eight. Montmorillonite tetrahedron layer containing $\mathrm{Si}^{4+}$ as the central atom, while $\mathrm{Al}^{3+}$ on the eight-shaped layer. The ability to absorb negative charges are coming from it. Montmorillonite neutralize the negative charge of the positive charge of pollutants and then will attract and capture pollutants in the surface of the adsorbent [8].

In the process analysis of multi variable, the conventional optimization techniques are done with one variable changes at a time while the other variable is fixed is impractical and does not represent the influence of the relationship between different factors. Therefore, we need a statistical tool to optimize the operating parameters simultaneously within the same time. Statistical analysis of experimental variables should also consider the relationship between variables. In this study, response surface method or response surface method (RSM) is one tool that is famous for collecting and mathematical modeling to determine the effects of various independent variables on the output. RSM is very useful to improve the precision of existing design using the minimum number of trials [9].

The most popular models on the RSM is a quadratic composite center or Central Composite Design (CCD). $\mathrm{CCD}$ is an efficient and flexible in providing sufficient data against the influences of variables and thus reducing the overall experimental error with fewer number of trials. In $\mathrm{CCD}$, four models offer useful data regarding 
direct, paired relationship and the effect of variable linear arc. The main advantages to apply RSM is the higher interaction between all process variables and lower runs of experiment which attributed to consuming time of the process compared the traditional optimizations.

Using membrane filtration process depends on the relationship between many factors. Modelling has many problems that cannot be solved with simple mathematical equations. Therefore, we need a sophisticated tool. Artificial fiber networks or artificial neural network (ANN) is a tool that is now commonly used by researchers to predict the content of the parameters [10].

Akratos [11] used ANN to design equations removal of BOD and COD. The results showed that the important parameters that affect the removal of BOD is pore media, waste water temperature and longtime stay. From ANN prediction, design equations hyperbole, which combines the zero-order kinetics and was first selected to predict the removal of BOD. The results of ANN and design equation models were compared with data that may be obtained from previous studies, which showed a correlation rather satisfactory. Enforced COD has been found to be strongly associated with the removal of BOD.

\section{Method}

The materials used in this study include: treating raw POME collected from one of the factories in Malaysia, $\mathrm{pH}$ adjustment is done with the addition of $\mathrm{NaOH}$ and $\mathrm{HCl}$, Montmorillonite purchased from Across Organics and used as received, UF membrane made of Polysulfone and RO membrane type of spiral made from Wong Jin Chemical China.

The equipment involved in this research is a set of chemical glassware, adsorption columns, centrifugal pump and a set of tools GDP artificial filtration membrane filter, Bandung. POME treatment processes carried out in three phases adsorption by montmorillonite, with UF membrane filtration and purification by RO membranes. In the first stage, $10 \mathrm{~L}$ POME processed through the adsorption column. Samples were inserted with the aid of a centrifugal pump with a flow rate of $2 \mathrm{~mL} / \mathrm{min}$. POME into the top of the column and then flow up and out at the bottom of the column. This process takes approximately 2 hours. POME partly absorbed by montmorillonite, are supplied to the UF membrane for further processing.

The treatment process uses UF membrane takes 1 hour. POME that have been processed by the UF membrane is passed directly to the RO membrane feed tank. Sampling on both the equipment performed every 30 minutes. Optimization used to statistically analyze tool ANNOVA with contour and response surface plot. Variable-dependent variables involved, namely: POME concentration, $\mathrm{pH}$, the transmembrane pressure (TMP), and the time of sample collection while the value of $\mathrm{BOD}, \mathrm{COD}$ and color to the independent variables.

To get a modelling of COD removal, is used Matlab 7.10.0 (R2010b The Math Works, Inc.). In this method algorithm used Lavenberg-Marquardt (LM). In the LM algorithm, there are two valid activation function is tan sigmoid function in the hidden layer and a linear function on the output layer. Data input will be divided into three parts: $70 \%$ for the training data, $15 \%$ for data validation and $15 \%$ for the test data. If the weight and bias have been determined, ANN ready for practice or training. ANN multi-layer flow can be trained to advanced mathematical functions (nonlinear regression) or determining patterns.

The circuit awoken comprised of three layers include layers of fill, one hidden layer and output layer. As we have chosen, three conditions namely POME concentration, $\mathrm{pH}$, the transmembrane pressure and filtration time as independent variables in the input layer while the COD, BOD and color as dependent variables in the output layer to the structure of six neurons in the hidden layer.

Analysis of samples includes BOD, COD, TSS, color, and turbidity. To identify the parameters of the reactor whereas the POME used COD BOD measurement is done in space incubator (Model 205) and tracks BOD (Model 26197-00) all from HACH, USA. For the analysis of TSS, the use of filter paper, vacuum filters and oven is the main equipment. Spectrophotometer HACH DR / 2010 is used for the analysis of COD, color and turbidity.

\section{Result and Discussion \\ 4.1. Pollutan Removal}

At the first stage, POME was treated by adsorption using montmorillonite. POME was fed from upper side of column and flow by gravitational through the montmorillonite. Adsorption by montmorillonite aims to eliminate TSS and turbidity which contribute not less than $50 \%$ of pollutants. The results showed that the adsorption process can get rid of the TSS and turbidity almost $100 \%$. POME that partly sorbet by montmorillonite will feeding to Ultrafiltration (UF) membrane.

Table 1. The results overall

\begin{tabular}{lccc}
\hline Parameter & $\begin{array}{c}\text { Initial POME } \\
\text { sample } \\
(\mathrm{mg} / \mathrm{L})\end{array}$ & $\begin{array}{c}\text { After } \\
\text { Pretreatment } \\
(\mathrm{mg} / \mathrm{L})\end{array}$ & $\begin{array}{c}\text { After } \\
\text { RO membrane } \\
(\mathrm{mg} / \mathrm{L})\end{array}$ \\
\hline BOD & 482 & 174.67 & 37 \\
COD & 2100 & 244.67 & 20.67 \\
TSS & 23300 & 7 & 0.6 \\
Colour & 7067 & 1263.33 & 28 \\
Turbidity & 3928 & 43.57 & 0.67 \\
\hline
\end{tabular}

Surface adsorbent has pores that can absorb the active particles in the POME. Montmorillonite has a negative charge comes from the replacement of ions on 
its surface. The positive charge of the particle will be met with a negative charge of the montmorillonite and neutralized. While the percentage of removal for the parameters BOD, COD and color has not shown good results. This may be due to lack of ions on the surface of montmorillonite to absorb organic molecules from POME. However, the adsorption by montmorillonite has managed to eliminate almost all the TSS and turbidity.

A decrease in the content of the pollutant parameters after UF membrane adsorption and increased well compared with treatment by adsorption alone. In addition to TSS and turbidity, removal percentage also increased for the parameters BOD, COD and color. This is due to the UF membrane materials that are hydrophobic is very suitable for the removal of particles of small size that cannot be removed by montmorillonite. Extra processing with UF membrane, is believed to eliminate organic molecules in POME. Allegedly POME are organic molecules in proteins and carbohydrates. The success of UF membrane to dispose of protein and carbohydrates have been studied by Wu et al. [12]. The treated POME will be feeding to Reverse Osmosis (RO) membrane.

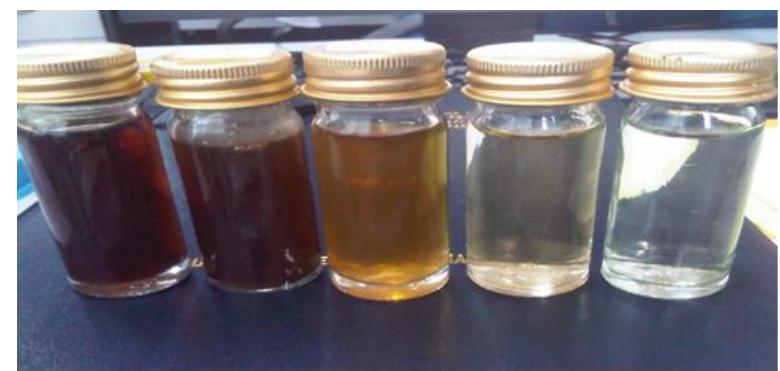

Figure 1. Performance of POME, before and after treatment

Overall combined (adsorption and membrane filtration) method has succeeded in eliminating almost all pollutants from POME. The overall result is presented in Table 1. The results of processing POME meet the standard release issued by the Ministry of Environment of the Government of Malaysia. The same results were obtained by other researchers [13][2]. The success of the removal of pollutants in POME shows that full tertiary treatment (adsorption, membrane UF and RO) is suitable for the treatment of POME as shown in Figure 1.

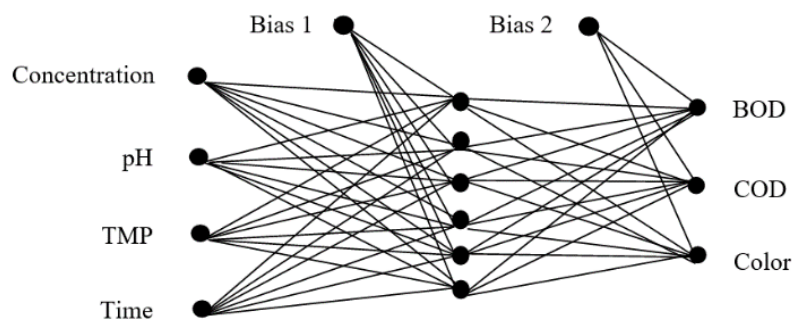

Figure 2. The architecture of ANNs

\subsection{Optimization with RSM and ANN}

To get a good quality product from RO membranes, optimization needs to be done with RSM treatment process by taking into account the relationship between variables-dependent variables and independent variables. Optimization based numerical methods used desirability selection is high (close to 1). From the analysis of selected data $15.77 \%$ concentration, $\mathrm{pH} 3.73$, and TMP $0.50 \mathrm{kPa}$ at an optimum point prediction removal of BOD, COD and color as much as $32.88 \mathrm{mg} / \mathrm{L}$, $47.98 \mathrm{mg} / \mathrm{L}$ and $26.52 \mathrm{PtCo}$, respectively.

In an effort to validate the trust models, another trial was run using the operating state of the method suggested by RSM. Small error value between experiment and prediction value shows that the method of CCD/RSM is one good tool to achieve the best operating conditions [14]. Table 2 validate the results of experiments carried out in three replications trials follow the recommended optimum operating conditions.

Table 2. Endorsement prediction values and the experimental results

\begin{tabular}{lccc}
\hline Parameter & $\begin{array}{c}\text { The experimental } \\
\text { results }(\mathrm{mg} / \mathrm{L})\end{array}$ & $\begin{array}{c}\text { Predicted value } \\
(\mathrm{mg} / \mathrm{L})\end{array}$ & $\begin{array}{c}\text { Correction } \\
(\%)\end{array}$ \\
\hline BOD & 32,66 & 32,88 & $-0,68$ \\
COD & 47,86 & 47,98 & $-0,26$ \\
Colour & 26,80 & 26,52 & 1,01 \\
\hline
\end{tabular}

ANN run using propagation algorithm behind or back propagation. Neural network with six neurons in each hidden layer and four inputs are used to propose the simulate model of COD, BOD and color. The architecture of a single hidden layer and an output layer was shown in Fig 2.

The development of ANN model included two steps as a training and validation. For the treatment with $\mathrm{RO}$ membrane, a total number of 324 experimental data were created. About 243 data apply for training and 81 data for validation of proposed ANN model. The results show the value of COD removal approaches the prediction with $\mathrm{R}^{2}$ values were found over 0.9 for all parameters. This phenomenon certifies the accuracy of ANN. ANN with six neurons in the hidden layer and four input parameters used in the model suggested to simulate the output value of COD, BOD and color. ANN mathematical model follows the following equation:

$Y=\sum_{n=1}^{n}\left\{\mathrm{Wo}_{(1, n)}\left[\frac{2}{1+\exp (-2) \sum_{\mathrm{m}=0}^{\mathrm{n}}\left(\mathrm{Wi}_{(\mathrm{n}, \mathrm{m})} \ln \ln _{(m)}+b 1_{(n)}\right.}-1\right]\right\}+b 2_{(l)}$

Where:

$\mathrm{n}$ is the number of hidden neurons,

$m$ is the number of inputs, 
1 is the linear output,

Wi and b1 is the weight and bias on the input layer to the hidden layer,

Wo and b2 are heavy and bias in the hidden layer to the output layer,

$\mathrm{Y}$ is the predicted parameter that is $\mathrm{COD}, \mathrm{BOD}$ and color.

Tangent hyperbolic "TANSIG" (ie a switchover function) has been selected for mapping input to the hidden layer when pure linear transfer function "PURELIN" has been selected for mapping hidden layer to the output layer. Heavy circuit and bias related to exclusion ANN model of COD, BOD and color listed in Table 3.

Table 3. weight bias circuit and ANN model for COD removal

\begin{tabular}{|c|c|c|c|c|c|c|}
\hline \multirow{2}{*}{ Neuron } & \multicolumn{4}{|c|}{$\mathrm{W}_{\mathrm{i}}$} & \multirow{2}{*}{ b1 } & \multirow{2}{*}{$b_{2}$} \\
\hline & Concentration & $\mathrm{pH}$ & TMP & Time & & \\
\hline 1 & -1.6418 & 1.0695 & -3.8884 & -0.044911 & 3.5633 & 0.27136 \\
\hline 2 & -4.0443 & 5.3732 & 0.25598 & 2.0763 & 0.84903 & 0.15934 \\
\hline 3 & 1.2197 & 1.1371 & -0.31881 & -0.0027809 & -1.4653 & -0.3892 \\
\hline 4 & 3.5744 & 6.5205 & 2.0026 & 0.094434 & 6.8339 & \\
\hline 5 & 1.531 & -0.95662 & 0.11425 & -0.01517 & -1.0172 & \\
\hline 6 & -4.5128 & 5.621 & 0.13695 & 0.33648 & 0.64359 & \\
\hline Output & $\mathrm{Wo}_{(1,1)}$ & $\mathrm{Wo}_{(1,2)}$ & $\mathrm{Wo}_{(1,3)}$ & $\mathrm{Wo}_{(1,4)}$ & $\mathrm{Wo}_{(1,5)}$ & $\mathrm{Wo}_{(1,6)}$ \\
\hline COD & -0.080188 & -0.16399 & 0.029091 & 0.029091 & 1.0826 & 0.51319 \\
\hline BOD & -0.27865 & -0.30863 & -0.66178 & -0.32838 & 1.3025 & 0.70999 \\
\hline Colour & 0.39307 & -0.20635 & -2.16 & -0.55507 & 3.0361 & 0.96809 \\
\hline
\end{tabular}

Further testing ANN models were obtained. It is used for testing other data. Overall the data involved in the modeling process includes 243 sets of data to process the exercises and 81 sets of data for the prediction. Shown in Figure 3, the COD value per unit time research results in line with prediction ANN value per unit time, consistent with earlier findings by some researchers [15][16].

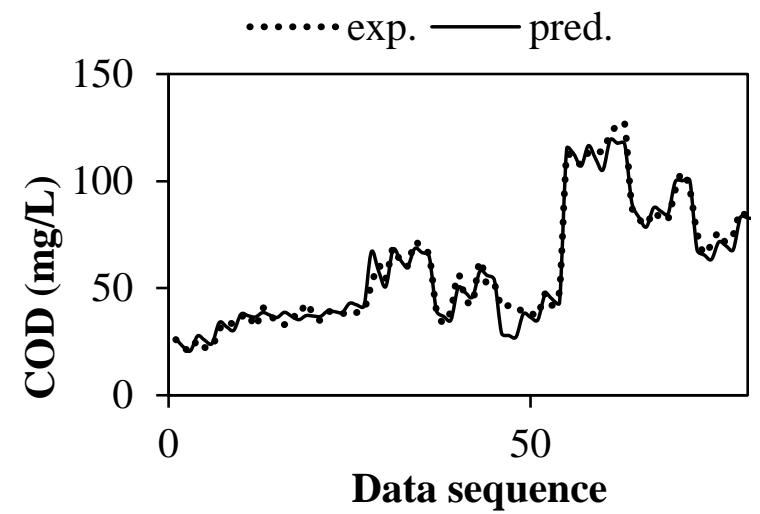

Figure 3. Ratification of the COD value research results and value prediction

5. Conclusion

From this research can be taken two conclusions:
The combined process of adsorption and membrane UF managed to reduce levels of BOD, COD, TSS, color, and opacity to $63 \%, 88 \%, 99 \%, 82 \%$ and $98 \%$. RO membrane process succeeded in reducing the levels of BOD, COD, TSS, color, and opacity to $92 \%, 98 \%, 99 \%$, 99\% and $99 \%$.

The optimum conditions in the processing using the RO membrane is achieved at a concentration of $15.77 \%, \mathrm{pH}$ 3.73 and $0.50 \mathrm{kPa}$ with errata TMP ranged $-0,68-1,01$. Research results in line with prediction values. With the help of RSM method and ANN, process optimization of COD removal can run well.

\section{Acknowledgements}

The author is grateful to Universiti Kebangsaan Malaysia (UKM) for supporting through the Beasiswa Zamalah Universiti Penyelidikan.

\section{References}

[1] A. N. Ma and A. S. H. Ong, "Pollution control in palm oil mills in Malaysia," J. Am. Oil Chem. Soc., vol. 62, no. 2, pp. 261-266, Feb. 1985.

[2] A. L. Ahmad, M. F. Chong, S. Bhatia, and S. Ismail, "Drinking water reclamation from palm oil mill effluent (POME) using membrane technology," Desalination, vol. 191, no. 1-3, pp. 35-44, May 2006.

[3] Y. ZHANG, L. YAN, X. QIAO, L. CHI, X. NIU, Z. MEI, and Z. ZHANG, "Integration of biological method and membrane technology in treating palm oil mill effluent," J. Environ. Sci., vol. 20, no. 5, pp. 558-564, Jan. 2008.

[4] P. E. Poh and M. F. Chong, "Development of anaerobic digestion methods for palm oil mill effluent (POME) treatment," Bioresour. Technol., vol. 100, no. 1, pp. 1-9, 2009.

[5] W. P. Wah, N. M. Sulaiman, M. Nachiappan, and B. Varadaraj, "Pre-treatment and membrane ultrafiltration using treated palm oil mill effluent (POME)."

[6] N. M. N. Sulaiman; C. K. Ling, "Membrane Ultrafiltration of Treated palm Oil Effluent (POME)," J. Teknol., vol. 41, pp. 113-120, 2004.

[7] A. L. Ahmad, M. F. Chong, and S. Bhatia, "A comparative study on the membrane based palm oil mill effluent (POME) treatment plant," J. Hazard. Mater., vol. 171, no. 1, pp. 166-174, 2009.

[8] F. Hussin, M. K. Aroua, and W. M. A. W. Daud, "Textural characteristics, surface chemistry and activation of bleaching earth: A review," Chem. Eng. J., vol. 170, no. 1, pp. 90-106, 2011.

[9] A. A. L. Zinatizadeh, A. R. Mohamed, M. D. Mashitah, A. Z. Abdullah, and M. H. Isa, "Optimization of pre-treated palm oil mill effluent digestion in an up-flow anaerobic sludge fixed film 
bioreactor: A comparative study," Biochem. Eng. J., vol. 35, no. 2, pp. 226-237, 2007.

[10] I. N. da Silva and R. A. Flauzino, "An approach based on neural networks for estimation and generalization of crossflow filtration processes," Appl. Soft Comput., vol. 8, no. 1, pp. 590-598, 2008.

[11] C. S. Akratos, J. N. E. Papaspyros, and V. A. Tsihrintzis, "An artificial neural network model and design equations for BOD and COD removal prediction in horizontal subsurface flow constructed wetlands," Chem. Eng. J., vol. 143, no. 1, pp. 96110, 2008.

[12] T. Y. Wu, A. W. Mohammad, J. Md. Jahim, and N. Anuar, "Palm oil mill effluent (POME) treatment and bioresources recovery using ultrafiltration membrane: Effect of pressure on membrane fouling," Biochem. Eng. J., vol. 35, no. 3, pp. 309317, 2007.

[13] G. Najafpour, H. A. Yieng, H. Younesi, and A. Zinatizadeh, "Effect of organic loading on performance of rotating biological contactors using Palm Oil Mill effluents," Process Biochem., vol. 40, no. 8, pp. 2879-2884, 2005.

[14] G. E. P. Box, J. S. Hunter, and W. G. Hunter, Statistics for experimenters: design, innovation, and discovery. Wiley-Interscience, 2005.

[15] F. S. Mjalli, S. Al-Asheh, and H. E. Alfadala, "Use of artificial neural network black-box modeling for the prediction of wastewater treatment plants performance," J. Environ. Manage., vol. 83, no. 3, pp. 329-338, 2007.

[16] E. S. Elmolla, M. Chaudhuri, and M. M. Eltoukhy, "The use of artificial neural network (ANN) for modeling of COD removal from antibiotic aqueous solution by the Fenton process," J. Hazard. Mater., vol. 179, no. 1, pp. 127-134, 2010. 